had been borne by the mother for twentynine years, and always declared by her whilo living to be a child.

Dr. S. S. Keenc, of Providence, reported a peculiar case of "Poisoning by external application of tincture of aconite root, through a wound in the index finger of the right hand," describing the effects of the poison, and the remedies effectually applied.

Dr. Albert G. Browning of Olneyville, next read a paper upon "Ileredity and IIereditary Influences." The theme of the essay was hereditary transmission of physical and moral peculiarities and qualities, and especially of diseases. He also discussed incidentally the theories of Spencer and Darwin on the propagation of species.

Dr. C. W. larsons, of P'rovidence, then presented and read to the meeting a paper on "The Medical Relations of the Ilydrate of Chloral." The paper of Dr. Parsons was long, but an able and exhaustive discussion and presentation of the merits of the new drug as a medicine, and especially a sleep producer.

The President invited remarks upon Dr. Parson's valuable paper, and 1)rs. O'Leary, Clapp, Caswell, Ballou, Newhall-all spoke of it in very complimentary terms, and gave their experience and methods of using chloral.

Dr. Clapp, of Pawtucket, moved that the paper be referred to the publication committee to be printed. $\Lambda$ fter some general discussion of the subject, at half-pist one o'clock a recess was taken to partake of the collation provided by the president.

On reiisscmbling, Dr. Cliarles 11 . Hisher, of Scituate, read a paper upon the subject of "'The Origin and Nature of Infectious Diseases."

'The essay, in short, was an ablo argument in finvor of the germinal theory of infectious diseases and contagion, and showed great familiarity with the most advanced modical investigations and scientific rescarch, in both $\Lambda$ merica and Europe.

'The lBoard of Censors reported that Dr. Charles II. Bogman, of Providence, and I)r. James ]3. Ilanaford, of Warwick, had submitted written applications for admission as l'ellows of the suciety, with the required recommendations. Upon the recommendation of the Censors, they were both uninimously elected.

On motion, it was voted to hold the next mecting of the Society in March, at the sime place, and the 'l'reusurer wiss instructed to provide a collation at that time at the expense of the Society.

The president read a communication (which he complimented as a model report, it being all written on a half-sheet of note paper) from a gentleman who has suffered for five years from a dischargo in his side after an attack of plourisy, and expressing the hope of obtaining relief by referring his case to the Medical Society. The communication was received and, after some discussion, was referred to the President.

Dr. Geo. E. Mason, of Providence, exhibited a liuman stomach diseased with cancer, preserved in alcohol, obtained from a paticnt who recently died at the Rhodo Island Ilospital.

Dr. (xcorge Capron, of Providence, reported two very interesting obstetrical cases which occurred in his practice, and the subject was discussed by Drs. Clapp, Brown and Garvin.

The l'resident then stated that the meeting was open for gencral discussion of any of the papers which have been read, and pertinent remarks upon the several subjects that had been presented wero made by Drs. Clapp, Garvin, lisher, Arnold and Brown.

On motion of Dr. Clapp, the thanks of tho Society were presented to the anthors of the valuable papers that had been read, and copies of the same wero requested to bo referred to the Publication Committeo for printing.

The meeting was then adjourned to meet again in the same place on tho third Weduesdity in March, at 10 o'clock, A.MI.

\section{Selecteiv olupers.}

\section{ABSCESS OF 'THE LIVER. RVACUA'TION BY} OP'BRA'TION. RECOVERY.

By H. M. S'тинкт,opr, M.I)., Carondelet, South St. l.ouis.

Mr. II., a German, aged 50 years, had suffered fiom various troubles for nearly eighteen months, the time since he had arrived in this country. Ho had been treated repeatedly for malarial troubles during this time. In August ho had suffered, jud ring from his own description of the case, fiom acute hepatitis, finding no relief.

On examination of the patient, I found him very much emaciated, complaining of constant and increasing pain in the shoulders and back; he was irrituble in temper; had eapricious appetite, languor, and persistent feverishness; was troubled with night sweats and had hectic fever; pulse 
small and rapid; complained of a burning sensation in the skin of the hands and feet; was sad and despondent, convinced that he would die. In fact, he presented all the symptoms indicative of suppurative inflammation of the liver. Besides the above, he complained of a deep-scated pain in the side. On inspecting the locality indicated by him as the place of pain, there was found a well-marked swelling with indurated base extending from the upperborder of the seventh rib to a point on a level with the lower border of the tenth rib, and about an inch and a half from the median plane of the body. Upon palpation fluctuation was evident. After this examination, the patient was informed plainly and truly of his condition, and one of two alternatives offered, either to run the extremely precarious risk of waiting for the abscess to point and discharge itself, or to have it at once emplied of its contents by means of the knife and trocar. The patient was perfectly willing to abide by my decision. There were reasonable grounds for believing that an external outlet for the pus was the direction taken by the abscess. Besides, there was a hardened base to the swelling, and tenderness. Picturing to mysclf the possible consequences of the delay-the risk of rupturing the walls of the abscess by coughing, sneezing or the like, and the laceration of any adhesions which might have formed-made me speak somewhat warmly in favor of opening at once.

Assisted by Dr. Outten, I proceeded with the operation. II aving determined as nearly as possible the limits of the abscess, the patient was laid upon his back, the upper part of his body bent forward, and the thighs somewhat flexed upon the abdomen. An incision about two inclies in length was made over the abscess, dividing the skin, subcutancous and adipose tissues, muscles, and aponeuroses. It was my intention to follow the plan of operation as recommended by Dr. Graves, of Mcath Ilospital, viz.: that an incision should be made through the skin, \&c., to within a few lines of the peritoneum, and the opening then plugged up with lint, with a view of inducing adhesion; but fecling the peritoncuin puffed out by the fluid behind, I determined at once to puncture and evacuate the contents of the abscess. Prior to evacuation, and desiring to avert danger as much as possible, a curved threaded needle was passed down the sides of the wound through the peritoneum, stitcling the peritoneum to both sides of the wound, aiming to prevent the possibility of pus getting within the cavity of the peritoneum. The patient was then held on the edge of the bed, so that the front of the body was directed downwards towards the floor, as I desired to get the assistance of gravity and pressure, thus compelling a freer flow of the contained matter. A trocar was pushed into the abscess and a thick, greenish pus of ammoniacal odor withdrawn. The canula was then left in the cavity of the abscess, retained in position by adhesive straps, for three days.

The patient living six or eight miles in the country, I was unable to see him daily; but on the day after the opening of the abscess I visited him, and found him in a worse condition than before the operation: pulse small, fluttering, about 100 per minute; skin clammy. The pus escaping was now changed somewhat in color, becoming chocolate, slightly thinner, and flowing freely. Bowels constipated; appetite of but little moment. Patient in a very prostrate condition. Quinine, acids and stimulants were freely administered, and injections of tepid water made to relieve the constipation. This condition of things continued for a week. On 'luesday of the second week lis condition was somewhat better; the discharge of pus lessened; skin moist but not clammy; slight appetite; bowels still inactive. From this time on his condition became daily better, so that by the end of the fifth week he had so far recovered that he was cnabled to go about; appetite returning; skin moist, normal; the bowels regular, and the discharges natural and properly colored. On Sunday, of the sixth week, he came to my office; there was no discharge of matter, the opening having closed; no pain on pressure, but a little induration of the liver. He expressed himsclf as feeling perfectly well. Up to this time the liver seems to be acting normally.-St. Louis Med. and Surg. Journal.

\section{A FULLY MA'TURED TANAIA SOLIUM OR TAPE-WORM EXPELLED FROM $\Lambda$ (JHILD FIVE DAYS OLD.}

By Saxued G. Almor, M.D.

Trie natural history of tape-worm parasites has been a subject of fruitful speculation, and, so far as I am aware, the casc here reported is quite unique. The tæuia solium, according to Kuichenmeister's investigations, " only occurs in children who partake of hog's meat." Neither he nor Cobbold makes mention of the possibilits of a fullymatured tenia occurring in infuntile peri- 